\title{
RELATIONSHIP MARKETING DIMENSIONS ON CUSTOMER SATISFACTION AND CUSTOMER LOYALTY - A REVIEW
}

\author{
Veena Kumari. C. $\mathbf{M}^{1 *}$
}

${ }^{* 1}$ Research Scholar PP.MAN. (0104), Rayalaseema University, Kurnool.

\section{*Corresponding Author: -}

\begin{abstract}
: -
Relationship marketing is frequently employed by firms to improve their dealings with customers. A key challenge for researchers is to identify and understand how different variables influence important relationship outcomes such as customer loyalty and customer satisfaction. This study aims at analyzing the existing dimensions and also in finding out those variables which are considered to be more effective in creating customer loyalty and customer satisfaction.
\end{abstract}

Keywords: - Relationship marketing dimensions, trust, commitment, customer satisfaction, customer loyalty 


\section{Aim of the study:}

The researcher aims to explore the various dimensions of Relationship Marketing that are used in the previous studies in the services sector. The following are the important objectives.

1. To find out the various Relationship Marketing dimensions that is applied in the previous studies.

2. To identify those dimensions that are considered to be more effective.

\section{Methodology}

A range of online databases were searched to provide a comprehensive listing of journal articles on the dimensions of Relationship Marketing. Out of thirty-five articles identified for the study eighteen articles were subsequently selected based on the major focus of the study. The bibliography provides an academic database of the literature between 1994 and 2015 covering 18 journals.

\section{INTRODUCTION}

In the words of Evert Gummesson (2002) "Relationship Marketing is marketing based on interactions within networks of relationships. A network is a set of relationships that can grow into enormously complex pattern. According to Leonard L. Berry (1983) Relationship marketing is attracting, maintaining and in multi service organizations enhancing customer relationships. Clive porter (1993) says "Relationship marketing is the process whereby both the parties establish an effective, efficient, enjoyable, enthusiastic and ethical relationship: one that is personally, professionally and profitably rewarding to both parties. Supriya Biswas(2014)

Though there is plethora of definitions on Relationship Marketing the choice between definitions is often a matter of convenience or researcher's orientation. The concept of RM has been translated into strategies and tactics and their perceived benefits.

\section{RM Dimensions}

The service providers require the knowledge of Relationship Marketing Dimensions for the purpose of building long term relationships with the customers that would pave way for the customer satisfaction and ultimately lead to customer loyalty.

\section{Trust}

Trust can be defined as "a willingness to rely on an exchange partner in whom one has confidence." (Moorman et al., 1993) It has been considered as one of the essential elements for a lasting relationship. Trust would strengthen a longterm relationship.

\section{Bonding}

Adewusi (2008) states in his study that higher the extent of bonding with the firm, more they tend to be loyal to such firms but absence of bond has a negative impact on customer relationship outcomes.

\section{Competence}

Selner (1998) states that competence is 'the buyer's perception of the supplier's technological and commercial competence". Once customers perceive the organization to be competent they are more likely to stay with them and hence can be used as a Relationship Marketing construct to study its effect on customer loyalty.

\section{Commitment}

According to Ndubisi (2006), commitment is a central expectation or norm within business relationships, while Lacey and Morgan (2007) found that commitment is well ingrained in the relationship literature and essential to the creation and protection of marketing relationships. Liang and Wang (2006) confirmed that commitment has an important role in relationship and found that commitment is remarkable when the relationships on both sides turn to be more stable.

\section{Communication}

Communication was formulated by Anderson and Narus (1990) as the exchange of timely information between firms. The customers have a variety of sources to receive the communications such as targeted magazines, on line sources, coupons etc. apart from this they also gain information from sources such as services capes, customer service departments and service encounter interactions with employees. Hence this paves way to establish relationship with customers.

\section{Conflict handling}

The overall level of disagreement in the working partnership (Anderson and Narus 1990). Conflict reflects the frustration between a buyer and a seller. Conflict handling is an opportunity for the company to show its client its efforts to resolve the conflict with an outcome of loyalty if it is executed efficiently.

\section{Empathy}

Seeking to understand the desires and goals of somebody else. (Sin et al 2005). It is defined as seeking to understand somebody elses' desires and goals. In the service marketing literature empathy is used in developing the SERVQUAL test instrument for service quality. 


\section{Reciprocity}

"The component of a business relationship that causes either party to provide favours or make allowances for the other in return for similar favours or allowances at a later stage" (Sin et al 2005)

\section{Relationship benefits}

"Partners that deliver superior benefits will be highly valued and firms will commit themselves to establishing, developing and maintaining relationships with such partners" Morgan \& Hunt (1994). For a long term relationship to exist, both the service provider and the customer must benefit from such a relationship. Such benefits would prompt the service providers to offer better services and also the customer to be loyal to the organization.

\section{Shared values}

The extent to which partners have beliefs in common about what behaviours, goals and policies are important, unimportant, appropriate or inappropriate, and right or wrong Morgan \& Hunt (1994)

\section{Service Quality}

Parasuraman et al (1988) defined service quality as the consumers' judgement about a firm's overall excellence or superiority. Delivering superior quality to the customers is central to the formation of customer loyalty (Zeithaml et al., 1996). Hence the competitive advantage of a service organization is determined by its ability to expand and maintain a large and loyal customer base.

\section{Technology}

Research suggests that effectively managing customers depends on the firm's ability to handle the changes resulting from the implementation of Information Technology and its ability to use resources to build relationships with customers (Payne and Frow, 2005).

\section{Customer Satisfaction}

According to Garbarino and Johnson (1999) satisfaction is 'an overall evaluation based on the total purchase and consumption experience with a good or service over time' Lovelock et al. (1998) listed the virtues of customer satisfaction: First, satisfaction is inextricably linked to customer loyalty and relationship commitment. Second, highly satisfied customers spread positive word of mouth and act as an advertisement for the organization whose service has pleased them. Third, highly satisfied customers may be more tolerant as they had enjoyed a good service delivery earlier. In the literature (Herrmann and Johnson, 1999; Dick and Basu, 1994) it is emphasised that there is a significantly positive correlation between customer satisfaction and the loyalty that customers feel towards a firm, but that a high degree of customer loyalty does not always have to be accompanied with a high degree of customer satisfaction.

\section{Customer Loyalty}

According to Payne \& Richard (1993), "relationship marketing focuses on clients' retention and building long term relations that, in exchange contributes to loyalty. The higher the satisfaction perceived by the client, higher the probability for long term relations and increased profitability". Customer loyalty is imperative if a company has to retain its existing customers. Service providers generally consider customer loyalty as an important source of competitive advantage (Woodruff, 1997) loyalty increases repurchase behavior because loyal customers demonstrate greater resistance to counter persuasion and negative word of mouth. Loyal consumers may be less price sensitive and decrease the risk of defection due to competitors' promotional activities (Stank et al., (2003)

\section{Literature Review}

David Bejou et al (1998) opine that from the customers' perspective the determinants of relationship satisfaction are thought to include factors such as customer orientation, trust, length of relationship, expertise and ethics. The study has identified the importance of trust and sales personnel's level of customer orientation on customers' perceived relationship satisfaction. Trust and expertise are seen as important influences on overall satisfaction with the relationship.

The study of banking clients in South Africa, Canada and the U.K.by C. Rootman, M. Tait \& G. Sharp(2011)

Revealed that six banking service delivery variables - communication, knowledgeabilty, empowerment, personalization, ethical behavior, fees, technology influence banks' relationship marketing and customer retention. Fee structures and ethical behavior of banks are regarded as the most important focus areas for banks.

Thorsten Hennig-Thurau et al (2002) have found out that the concepts of customer satisfaction, commitment, confidence benefits and social benefits have contributed significantly to relationship marketing outcomes. Relationship quality and Relationship benefits have been taken as two approaches to understanding customer loyalty and word of mouth. Customer satisfaction and commitment have been taken as Relationship quality dimensions that mediate between three relational benefits ie., confidence benefits, social benefits and special treatment benefits.

Robert W. Palmatier et al (2005) in their meta analysis however are of the opinion that relationship quality influences 
the performance of the organization rather than commitment. They have analysed the effect of customer focal relational mediators viz, commitment, Trust, Relationship satisfaction and relationship quality on customer, Seller and Dyadic Antecedents to produce various outcomes that include customer loyalty and Word of Mouth.

Mihir Dash and Vineetha Rajshekhar have examined Relationship Marketing in the context of banking considering five dimensions viz Trust, Bonding, Communication, Relationship Quality and conflict handling. They reveal that communication and conflict handling were significant drivers of overall customer satisfaction.

Edwin Theron and Nic S. Terblanche (2009) have in their study identified ten important dimensions although marketing literature reveals twenty three dimensions. Out of these dimensions trust, commitment, communication and satisfaction are recognised to be more valuable than relationship benefits, bonding, attractiveness to alternatives, customization and shared values

Ashish Gupta and G.P. Sahu (2015) provide empirical evidence of relationship marketing dimensions- trust, long term relationship, technology orientation, service quality, satisfaction, loyalty programmes and brand image having the influence on customer loyalty. They insist that trust, long term relationship orientation, good quality services to handle the complaints and updated technology in mobile services should be maintained to satisfy the customers

Robert.M.Morgan and Shelby D.Hunt (1994) theorize that the presence of relationship commitment and trust is central to successful relationship marketing. When both trust and Commitment are available they produce relationship outcomes that would promote productivity and effectiveness. Trust and Commitment are pivotal since they encourage the service providers to work at preserving relationship and resist short term alternatives from competitors.

Ibok, Nkanikpo Sampson, Emem Akaninyene (2014) examine the relative influence of various relationship marketing dimensions of trust, reciprocity, empathy and bonding on the effectiveness of relationship marketing within the context of Nigerian telecommunication industry. Customers loyalty as an important mediating role between the independent variables (trust, reciprocity, empathy and bonding) and the dependent variable (relationship Marketing) is supported in this study as in many other studies.

Bilal Afsar, Zia Ur Rehman, Jaweria Andleeb Qureshi and Asad Shahjehan (2010) have researched to find the factors of customer loyalty and their relationships with the banking industry in Pakistan. Perceived quality, trust, satisfaction, commitment and switching cost are found to be the factors that affect the loyalty of the customers.

Faizan Mohsan et al (2011) researched the impact of customer satisfaction on customer loyalty in the banking sector of Pakistan and found that Customer satisfaction greatly influences the customers' repurchase intentions whereas dissatisfaction has been seen as a primary reason for customers' intentions to switch. They claim that products offered by the bank and the service quality are pre requisite for satisfying and retaining valued customers.

Rizwan Ali et al (2014) in their study on customer loyalty in Pakistan Banking Industry indicate that service quality, trust and reputation positively influence customer's loyalty. And there is also significant correlation among service quality, trust and reputation.

Hafiz Muhammad et al (2015) investigated the factors of customer loyalty to find out their influence on the behavior 
and intentions of the respondents. They examined the relationship of trust, customer satisfaction and service quality with customer loyalty to determine which factor influenced customer loyalty the most. They observed that customer satisfaction is found to be the most influential variable for customer loyalty. Here the customer satisfaction has been used as one of the independent variables.

Lo Liang Kheng et al (2010) have evaluated the impact of service quality on customer loyalty among bank customers in Penang, Malaysia with customer satisfaction mediating these variables. Out of the Service quality -dimensions Tangibles, Reliability, Responsiveness, Empathy, Assurance, they comment that reliability, empathy, and assurance play a significant role in enhancing the customer loyalty.

Nelson Oly Ndubsi (2007) examined the relationship marketing strategy on customer loyalty. He has identified that Trust, Commitment, conflict handling and communication are the four underpinnings of relationship marketing that are directly linked to and are capable of predicting customer loyalty.

Mohammad Taleghani et al (2011) have investigated the impact of relationship marketing underpinnings namely trust, commitment, communication, conflict handling, bonding, shared values, empathy, and reciprocity on customer loyalty in the banking industry. They observe that these relationship marketing constructs are directly associated with customer loyalty and they have a significant effect on it.

Peter Anabila, Dr Bedman Narteh (2012) in their inquiry into the relationship between Relationship Marketing (RM) and customer loyalty in Ghana's banking industry found that the six RM constructs Trust, communication, social and Financial Bonds, conflict handling, commitment and competence cumulatively had significant positive effect on customer loyalty. Individually, competence, commitment and communication were found to be significant drivers of customer loyalty.

Laith Alrubaiee, Nahla Al-Nazer(2010) investigated the impact of relationship marketing orientation on customer loyalty. They confirm that trust, communication, satisfaction, Bonding and commitment help in building the customer loyalty. They affirm Relationship bonding to be one of key strategic issues for establishing and maintaining long-term relationships with their customers.

\section{Discussion}

Marketing literature presents various studies with the application of different dimensions of RM but this study gives a comprehensive list of dimensions that are found to be effective. The first objective of the study was to identify the dimensions of RM that are focused in the previous studies. Accordingly 25 dimensions were recognized in 18 articles that were taken up for the study. The secondary objective was to identify the ones that are more effective. The following table presents the dimension that are used in diverse studies and also those dimensions that have been found to be effective. 


\begin{tabular}{|c|c|c|c|c|}
\hline No & Author & Dimensions used & $\begin{array}{l}\text { Effective } \\
\text { Dimensions }\end{array}$ & Outcomes \\
\hline 1 & $\begin{array}{l}\text { David Bejou, Christine } \mathrm{T} \text {. } \\
\text { Ennew, Adrian Palmer }\end{array}$ & \begin{tabular}{|l|}
$\begin{array}{l}\text { customer } \\
\text { orientation, trust, } \\
\text { length of } \\
\text { relationship, } \\
\text { expertise and ethics }\end{array}$ \\
\end{tabular} & $\begin{array}{l}\text { Trust } \\
\text { expertise }\end{array}$ & $\begin{array}{l}\text { Customer } \\
\text { satisfaction }\end{array}$ \\
\hline 2 & $\begin{array}{l}\text { C. Rootman, M. Tait \& G. } \\
\text { Sharp }\end{array}$ & $\begin{array}{l}\text { communication, } \\
\text { knowledgeabilty, } \\
\text { empowerment, } \\
\text { personalization, } \\
\text { ethical behavior, } \\
\text { fees, technology }\end{array}$ & $\begin{array}{l}\text { Fee } \\
\text { and } \\
\text { behavior }\end{array}$ & $\begin{array}{l}\text { Customer } \\
\text { Retention }\end{array}$ \\
\hline 3 & $\begin{array}{l}\text { Thorsten Hennig-Thurau, } \\
\text { Kevin P. Gwinner, } \\
\text { Dwayne D. Gremler }\end{array}$ & $\begin{array}{l}\text { customer } \\
\text { satisfaction, } \\
\text { commitment, } \\
\text { confidence benefits } \\
\text { and social benefits }\end{array}$ & $\begin{array}{l}\text { customer } \\
\text { satisfaction, } \\
\text { commitment, } \\
\text { confidence and } \\
\text { benefits social benefits } \\
\text { socila }\end{array}$ & $\begin{array}{l}\text { Customer loyalty } \\
\text { and Word of } \\
\text { Mouth. }\end{array}$ \\
\hline 4 & $\begin{array}{l}\text { Robert } \text { W. Palmatier, } \\
\text { Rajiv P. Dant, Dhruv } \\
\text { Grewal, Kenneth R. Evans }\end{array}$ & $\begin{array}{|lr|}\text { Commitment, } & \text { Trust, } \\
\text { Relationship } & \\
\text { satisfaction } & \text { and } \\
\text { relationship quality } \\
\text { on customer, Seller } \\
\text { and } \\
\text { Antecedents }\end{array}$ & $\begin{array}{l}\text { Conflict } \\
\text { handling, seller } \\
\text { expertise, } \\
\text { communication }\end{array}$ & 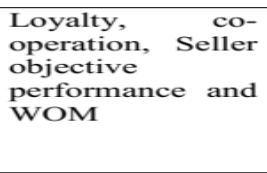 \\
\hline 5 & $\begin{array}{l}\text { Mihir Dash and Vineetha } \\
\text { Rajshekhar A }\end{array}$ & \begin{tabular}{|l|} 
Trust, Bonding, \\
Communication, \\
Relationship Quality \\
and conflict \\
handling \\
\end{tabular} & $\begin{array}{l}\text { communication } \\
\text { and conflict } \\
\text { handling }\end{array}$ & $\begin{array}{l}\text { Customer } \\
\text { satisfaction }\end{array}$ \\
\hline 6 & $\begin{array}{l}\text { Edwin Theron and Nic S. } \\
\text { Terblanche }\end{array}$ & $\begin{array}{l}\text { trust, commitment, } \\
\text { communication, } \\
\text { satisfaction, } \\
\text { relationship } \\
\text { benefits, bonding, } \\
\text { attractiveness to } \\
\text { alternatives, } \\
\text { customization and } \\
\text { shared values } \\
\text { (1more) }\end{array}$ & $\begin{array}{l}\text { trust, } \\
\text { commitment, } \\
\text { communication } \\
\text { and satisfaction }\end{array}$ & $\begin{array}{l}\text { Long term } \\
\text { marketing } \\
\text { relationships }\end{array}$ \\
\hline \multirow[t]{2}{*}{7} & $\begin{array}{l}\text { Ashish Gupta and G.P. } \\
\text { Sahu }\end{array}$ & \begin{tabular}{|l|} 
\\
\\
relationst, long term
\end{tabular} & $\begin{array}{l}\text { trust, long term } \\
\text { relationship }\end{array}$ & $\begin{array}{l}\text { Customer } \\
\text { satisfaction }\end{array}$ \\
\hline & & $\begin{array}{l}\text { technology } \\
\text { orientation, service } \\
\text { quality, satisfaction, } \\
\text { loyalty programmes } \\
\text { and brand image }\end{array}$ & $\begin{array}{l}\text { orientation, good } \\
\text { quality services } \\
\text { to handle the } \\
\text { complaints and } \\
\text { updated } \\
\text { technology }\end{array}$ & \\
\hline 8 & $\begin{array}{l}\text { Robert.M.Morgan } \\
\text { Shelby D.Hunt }\end{array}$ & $\begin{array}{l}\text { Trust and } \\
\text { Commitment }\end{array}$ & $\begin{array}{l}\text { Trust and } \\
\text { Commitment }\end{array}$ & $\begin{array}{l}\text { Successful } \\
\text { Relationship } \\
\text { Marketing }\end{array}$ \\
\hline 9 & $\begin{array}{l}\text { Ibok, Nkanikpo Sampson, } \\
\text { Emem Akaninyene }\end{array}$ & $\begin{array}{l}\text { Trust, reciprocity, } \\
\text { empathy } \\
\text { bonding }\end{array}$ & $\begin{array}{l}\text { Trust, } \\
\text { reciprocity, and } \\
\text { empathy } \\
\text { bonding }\end{array}$ & $\begin{array}{l}\text { Long term and } \\
\text { enduring } \\
\text { Relationships }\end{array}$ \\
\hline 10 & $\begin{array}{l}\text { Bilal Afsar, Zia Ur } \\
\text { Rehman, Jaweria Andleeb } \\
\text { Qureshi and Asad } \\
\text { Shahjehan and A }\end{array}$ & $\begin{array}{l}\text { Perceived quality, } \\
\text { satisfaction, trust, } \\
\text { switching cost and } \\
\text { commitment }\end{array}$ & $\begin{array}{l}\text { Satisfaction, } \\
\text { commitment and } \\
\text { switching cost. }\end{array}$ & Customer loyalty \\
\hline 11 & $\begin{array}{l}\text { Faizan } \\
\text { Muhamman, } \\
\text { Nawaz, Musarrat } \\
\text { Zeeshan Shaukat, Numan, } \\
\text { Aslam }\end{array}$ & $\begin{array}{l}\text { Customer } \\
\text { satisfaction ( with } \\
\text { Service product, } \\
\text { service quality as } \\
\text { pre requisites) }\end{array}$ & $\begin{array}{l}\text { Customer } \\
\text { satisfaction }\end{array}$ & Customer loyalty \\
\hline 12 & $\begin{array}{l}\text { Rizwan Ali, } \\
\text { Gao Leifu, } \\
\text { Rehmaniz }\end{array}$ & $\begin{array}{l}\text { Service quality, trust } \\
\text { and reputation }\end{array}$ & $\begin{array}{l}\text { Service quality, } \\
\text { trust } \\
\text { reputation }\end{array}$ & Customer loyalty \\
\hline 13 & $\begin{array}{l}\text { Hafiz Muhammad Wasif } \\
\text { Rasheed, Naeem Muhammad Shahid, } \\
\text { Sajid, Naeem } \\
\text { Mehboob Ahmad, Jumaid } \\
\text { Khalid, Hafiz Muhammad } \\
\text { Usman Khizar, Waseem } \\
\text { Ahmad Khan }\end{array}$ & $\begin{array}{l}\text { Trust, customer } \\
\text { satisfaction and } \\
\text { service quality and }\end{array}$ & $\begin{array}{l}\text { Customer } \\
\text { satisfaction }\end{array}$ & Customer loyalty \\
\hline 14 & $\begin{array}{l}\text { Lo Liang Kheng, Osman } \\
\text { Mahamad, T. Ramayah, } \\
\text { Rahim Mosahab, }\end{array}$ & $\begin{array}{l}\text { Service quality }- \\
\text { dimensions } \\
\text { Tangibles, } \\
\text { Reliability, } \\
\text { Responsiveness, } \\
\text { Empathy, } \\
\text { Assurance, }\end{array}$ & $\begin{array}{l}\text { Reliability, } \\
\text { empathy, and } \\
\text { assurance }\end{array}$ & Customer loyalty \\
\hline 15 & Nelson Oly Ndubsi & $\begin{array}{l}\text { Trust, Commitment, } \\
\text { conflict handling } \\
\text { and communication }\end{array}$ & $\begin{array}{l}\text { Trust, } \\
\text { Commitment, } \\
\text { conflict handling } \\
\text { and } \\
\text { communication }\end{array}$ & Customer loyalty \\
\hline \multirow[t]{2}{*}{16} & $\begin{array}{l}\text { Mohammad Taleghani } \\
\text { Shahram Gilaninia }\end{array}$ & $\begin{array}{l}\text { Trust, commitment, } \\
\text { communication, }\end{array}$ & $\begin{array}{l}\text { Trust, } \\
\text { commitment, }\end{array}$ & Customer loyalty \\
\hline & Seyyed Javad Mousavian & $\begin{array}{l}\text { conflict handling, } \\
\text { bonding, } \\
\text { shared } \\
\text { values, empathy, } \\
\text { and reciprocity }\end{array}$ & $\begin{array}{l}\text { communication, } \\
\text { conflict handling, } \\
\text { bonding, shared } \\
\text { values, empathy, } \\
\text { and reciprocity }\end{array}$ & \\
\hline 17 & $\begin{array}{l}\text { Peter Anabila, Dr Bedman } \\
\text { Narteh }\end{array}$ & $\begin{array}{l}\text { Trust, } \\
\text { communication, } \\
\text { social and Financial } \\
\text { Bonds, conflict } \\
\text { handling, } \\
\text { commitment and } \\
\text { competence }\end{array}$ & $\begin{array}{l}\text { Competence } \\
\text { commitment and } \\
\text { communication, }\end{array}$ & Customer loyalty \\
\hline 18 & $\begin{array}{l}\text { Laith Alrubaiee, Nahla } \\
\text { Al-Nazer }\end{array}$ & $\begin{array}{l}\text { trust, } \\
\text { communication, } \\
\text { satisfaction, } \\
\text { Bonding an } \\
\text { commitment }\end{array}$ & $\begin{array}{l}\text { Relationship } \\
\text { bonding }\end{array}$ & Customer loyalty \\
\hline
\end{tabular}

In all the articles that were taken for the study Trust was found to be a most commonly used dimension that was found in 12 studies, followed by commitment in 8 studies, communication in 7 studies, conflict handling in 5 studies, service quality in 3 studies, empathy, relationship quality, shared values, technology and customer satisfaction in 2 studies. 
Customer satisfaction has been interchangeably used as a dimension as well as Relationship outcomes. The other dimensions that have been used only once in the studies are expertise, knowledgeability, empowerment, personalization, ethical behavior, relationship satisfaction, competence, relationship benefits, customization, switching cost, fees and reputation. However when it comes to the effectiveness the studies reveal that it is the trust which is highly potent, followed by commitment, customer satisfaction, conflict handling, communication, empathy, bonding.

The following table reveals the number of studies that have found the stated dimensions to be effective:

\begin{tabular}{|l|l|}
\hline Dimension & $\begin{array}{l}\text { No. of studies } \\
\text { finding } \\
\text { Effectiveness }\end{array}$ \\
\hline Trust & 8 \\
\hline Commitment & 7 \\
\hline $\begin{array}{l}\text { Customer } \\
\text { satisfaction }\end{array}$ & 5 \\
\hline Conflict handling & 5 \\
\hline Communication & 6 \\
\hline Empathy & 3 \\
\hline Bonding & 3 \\
\hline others & 1 \\
\hline
\end{tabular}

\section{Conclusion}

The strategies that could be used effectively depend upon the particular type of service industry. The Education industry which comprises of pure services that are highly intangible and inseparable may find communication and knowledgeability as more dominant whereas Banking industry may find Trust, commitment and conflict handling to be more effective. However the relationship strategies not only help understand customer needs but also steer towards customer satisfaction that can direct to achieve customer loyalty.

\section{References:}

[1].Adewusi A.I.(2008) Marketing implications of Relationship Programmes, Journal of value creation 1 (2):38-52

[2].Anderson, J. and Narus, J. (1990) A model of distributor firm and manufacturer firm working partnerships. Journal of Marketing, 54, 1, pp. 42-58

[3].Bilal Afsar, Zia Ur Rehman, Jaweria Andleeb Qureshi and Asad Shahjehan (2010), "Determinants of Customer Loyalty in the Banking Sector: The case of Pakistan", African Journal of Business Management, vol.4 (6), p.p. 1040-1047.

[4].C. Rootman, M. Tait \& G. Sharp (2011) "Relationship marketing and customer retention lessons for South African banks". Southern African Business Review Volume 15 Number 3

[5].David Bejou, Christine T. Ennew, Adrian Palmer (1998) Trust, ethics and relationship satisfaction. International Journal of Bank Marketing 16/4 170-175

[6].Dick, A. and Basu, K. (1994) 'Customer loyalty: toward an integrated conceptual framework',

[7].Journal of the Academy of Marketing Science, Vol. 22, No. 2, pp.99-113.

[8].Edwin Theron and Nic S. Terblanche (2009) 'Dimensions of relationship marketing in business- to-business financial services' International Journal of Market Research Vol. 52 Issue

[9].Faizan Mohsan, Muhammad Musarrat Nawaz, M. Sarfraz Khan, Zeeshan Shaukat, Numan Aslam (2011) 'Impact of Customer Satisfaction on Customer Loyalty and Intentions to Switch: Evidence from Banking Sector of Pakistan’ International Journal of Business and Social Science Vol. 2 No. 16;

[10]. Garbarino, E. \& Johnson, M.S. (1999), "The different roles of satisfaction, trust and commitment in customer relationships". Journal of Marketing, 63, 2, pp. 70-87.

[11]. Gupta, A. and Sahu, G.P.(2015) 'Exploring relationship marketing dimensions and their effect on customer loyalty - a study of Indian mobile telecom market', Int. J. BusinessInnovation and Research, Vol. 9, No. 4, pp.375-395.

[12]. Hafiz Muhammad Wasif Rasheed, Muhammad Sajid, Naeem Shahid, Mehboob Ahmad, Junaid Khalid, Hafiz Muhammad Usman Khizar, Waseem Ahmad Khan (2015), 'Factors affecting Customer Loyalty in Banking Sector: A study on Banks in Bahawalpur (Pakistan)' International Journal of Accounting and Financial Reporting Vol. 5, No. 1

[13]. Herrmann, A. and Johnson, M.D. (1999) 'Die Kundenzufriedenheit als Bestimmungs-faktor der Kundenbindung', Zeitschrift für betriebswirtschaftliche Forschung, Vol. 51, pp.579-598.

[14]. Ibok, Nkanikpo Sampson, Emem Akaninyene (2014), Factors Affecting the Effectiveness of Relationship Marketing in the Nigerian Telecommunication Industry: The Customers Perspective International Journal of Managerial Studies and Research (IJMSR) Volume 2, Issue 10, PP 94-101 ISSN 2349-0330 (Print) \& ISSN 23490349 (Online)

[15]. Lacey, R. \& Morgan, R.M. (2007) Committed customers as strategic marketing resources.

[16]. Journal of Relationship Marketing, 6, 2, pp. 51-65.

[17]. Laith Alrubaiee, Nahla Al-Nazer (2010) 'Investigate the Impact of Relationship Marketing Orientation on 
Customer Loyalty: The Customer's Perspective’ International Journal of Marketing Studies Vol. 2, No. 1;

[18]. Liang, C.-J. \& Wang, W.-H. (2006) "The behavioural sequence of the financial services industry in Taiwan: service quality, relationship quality and behavioural loyalty”. Services Industries Journal, 26, 2, pp. 119-145.

[19]. Lo Liang Kheng, Osman Mahamad, T. Ramayah, Rahim Mosahab, (2010), "The Impact of Service Quality on Customer Loyalty: A study of banks in Penang, Malaysia”, International Journal of Marketing Studies vol.2, No.2

[20]. Lovelock, C.H., Patterson, P.G. and Walker, R.H. (1998) Services marketing: Australia and New Zealand, Prentice-Hall, Sydney, Australia.

[21]. Mihir Dash and Vineetha Rajshekhar A Comparison Of Relationship Marketing In Public And Private Sector Banks In India Electronic copy available at: http://ssrn.com/abstract=2190064

[22]. Mohammad Taleghani, Shahram Gilaninia, Seyyed Javad Mousavian (2011), "The Role of Relationship Marketing in Customer Orientation Process in the Banking Industry with focus on Loyalty" (Case Study: Banking Industry of Iran) International Journal of Business and Social Science Vol. 2 No. 19

[23]. Moorman, C. Deshpande, R. and Zaltman, G. (1993) Factors affecting Trust in market research relationships. Journal of Marketing, 57 (8) 1-101

[24]. Morgan, R.M. \& Hunt, S.D. (1994) The commitment-trust theory of relationship marketing.

[25]. Journal of Marketing, 58, 3, pp. 20-38.

[26]. Morgan, R.M. and Hunt, S.D. (1994) 'The commitment-trust theory of relationship marketing', Journal of Marketing, Vol. 58, No. 3, pp.20-38.

[27]. Ndubisi, N.O. (2006) "A structural equation modelling of the antecedents of relationship quality in the Malaysia banking sector". Journal of Financial Services Marketing, 11, 2, pp. 131-141.

[28]. Nelson Oly Ndubsi (2007) 'Relationship marketing and customer Loyalty' Marketing Intelligence \& Planning Vol. 25 No. 1, pp. 98-106

[29]. Parasuraman, A., Zeithaml, V.A. and Berry, L.L. (1988) 'SERVQUAL: a multiple- item scale for measuring customer perceptions of service quality', Journal of Retailing, Vol. 64, No. 1, pp.12-40.

[30]. Payne, A. and Frow, P. (2005) 'A strategic framework for customer relationship management',

[31]. Journal of Marketing, Vol. 69, No. 4, pp.167-176.

[32]. Payne, A. and Richard, J.. Relationship Marketing, Customer Retension and Service Firm Profitability. Melbourne University

[33]. Peter Anabila, Dr Bedman Narteh (2012) 'Relationship Marketing Practices and Customer Loyalty: Evidence from the Banking Industry in Ghana' European Journal of Business and Management www.iiste.org (Online) Vol 4, No.13.

[34]. Rizwan Ali, Professor Gao Leifu, Ramiz ur Rehman (2014), 'Factors Influencing Customer Loyalty of Banking Industry: Empirical Evidence from Pakistan', International Journal of Learning \& Development, Vol. 4, No. 2

[35]. Robert W. Palmatier, Rajiv P. Dant, Dhruv Grewal, Kenneth R. Evans (2005) "Factors Influencing the Effectiveness of Relationship Marketing': A Meta-Analysis 'Journal of Marketing

[36]. Robert.M.Morgan and Shelby D.Hunt (1994), The Commitment -Trust theory of Relationship Marketing, Journal of marketing vol 58, 20-38

[37]. Selnes, F. (1998) Antecedents and consequences of trust and satisfaction in buyer-seller relationships. European Journal of Marketing, 32, 3/4, pp. 305-322.

[38]. Sin,L.Y.M, Tse, A.C.B., Yau, O.H.M., Chow, R.P.M., Lee, J.S.Y. and Lau, L.B.Y. (2005),

[39]. "Relationship marketing orientation: Scale Development and Cross-cultural Validation". Journal of Business Research, 58,2, p.p. 185-194.

[40]. Stank, T.P., Goldsby, T.J., Vickery, S.K. and Savitskie, K. (2003) 'Logistics service performance: estimating its influence on market share', Journal of Business Logistics, Vol. 24, No. 1,pp.27-55.

[41]. Supriya Biswas (2014) Relationship Marketing Concepts, Theories and Cases, second edition, p8.

[42]. Thorsten Hennig-Thurau, Kevin P. Gwinner, Dwayne D. Gremler (2002) "Understanding Relationship Marketing Outcomes: An Integration of Relational Benefits and Relationship Quality" Journal of Service Research, Volume 4, No. 3, 230-247

[43]. Woodruff, R.B. (1997) 'Customer value: the next source for competitive advantage', Journal of theAcademy of Marketing Science, Vol. 25, No. 2, pp.139-153.

[44]. Zeithaml, V.A., Berry, L.L. and Parasuraman, A. (1996) 'The behavioural consequences of service quality', Journal of Marketing, Vol. 60, pp.31-46. 